\title{
HUBUNGAN USIA REPRODUKSI DENGAN KEJADIAN MIOMA UTERI DI RSUP. PROF. DR. R.D. KANDOU MANADO
}

\author{
${ }^{1}$ Lilis Pratiwi \\ ${ }^{2}$ Eddy Suparman \\ ${ }^{2}$ Freddy Wagey \\ ${ }^{1}$ Kandidat Skripsi Fakultas Kedokteran Universitas Sam Ratulangi Manado \\ ${ }^{2}$ Bagian Obstetri-Ginekologi Fakultas Kedokteran Universitas Sam Ratulangi Manado \\ Email: wiwie_pooh@yahoo.com
}

\begin{abstract}
Age is the most significant risk factor for the development of myoma uteri. The issue of myoma uteri in women's reproductive health continues to increase. The high incidence of myoma uteri between the ages of 35-50 years shows an association of myoma uteri with estrogen. This study aimed to determine the relationship between the incidence of myoma uteri during this stage in the RSUP Prof. Dr. R.D. Manado Kandou from March until October 2012. This study was a retrospective observational descriptive analytic crosssectional approach. This was carried out by using the Chi Square. A 95\% confidence level ( $\alpha$ $\leq 0.05$ ) and $P \leq 0.05$ showed there was a relationship between the independent variables and dependent variables. Based on 353 cases of all diseases in the Obstetrics-Gynecology section between the ages of 18-49 years, those who suffered from myoma uteri were 108 cases. Those aged between 34-49 years (101 cases, 93.5\%), suffered most from of myoma uteri while those aged between 18-33 were only 7 cases (6.5\%). The Pearson Chi-Square test value was 43.394 and obtained $P=0.000$. These results indicated there was a very significant correlation between the incidence of reproductive ages with myoma uteri $(P=0.000 ; \alpha=0.01)$. Conclusion: the high incidences of myoma uteri during reproductive ages showed no association with estrogen myoma uteri.
\end{abstract}

Keywords: reproductive age, myoma uteri.

\begin{abstract}
Abstrak: Usia merupakan faktor risiko yang paling bermakna untuk perkembangan mioma uteri. Salah satu masalah kesehatan reproduksi wanita ialah mioma uteri dengan insidensi yang terus meningkat. Tingginya kejadian mioma uteri antara usia 35-50 tahun menunjukkan adanya hubungan mioma uteri dengan estrogen pada usia reproduksi. Penelitian ini bertujuan untuk mengetahui hubungan usia reproduksi dengan kejadian mioma uteri di RSUP Prof. Dr. R. D. Kandou Manado periode Maret sampai dengan Oktober 2012. Penelitian ini bersifat observasi analitik deskriptif retrospektif dengan cross sectional design. Uji statistik menggunakan Chi square test. Dengan tingkat kepercayaan 95\% $(\alpha \leq 0,05)$, jika $P \leq 0,05$ maka terdapat hubungan antara variabel bebas dan variabel terikat. Dari 353 kasus untuk semua penyakit ginekologi di Bagian Obstetri-Ginekologi yang berusia antara18-49 tahun, terdapat 108 kasus dengan mioma uteri. Usia 34-49 tahun merupakan kasus terbanyak dengan mioma uteri yaitu 101 kasus (93,5\%); dan yang berusia 18-33 tahun terdapat tujuh kasus (6,5\%). Uji Pearson Chi-Square memperlihatkan nilai 43,394 dengan $P=0,000$. Hasil ini menunjukkan terdapat hubungan yang sangat bermakna antara usia reproduksi dengan kejadian mioma uteri $(P=0,000 ; \alpha=0,01)$. Simpulan: Dari hasil penelitian di Bagian Obstetri-Ginekologi RSUP Prof. Dr. R.D. Kandou Manado periode 1 Maret - 31 Oktober 2012 diperoleh bahwa kasus ginekologi terbanyak pada pasien berusia 18-49 tahun ialah mioma uteri, dengan usia tersering 34-49 tahun.
\end{abstract}

Kata kunci: usia reproduksi, mioma uteri. 
Salah satu hal penting untuk mencapai derajat kesehatan yang optimal ialah dengan memperhatikan kesehatan wanita, khususnya kesehatan reproduksi karena hal tersebut berdampak luas, menyangkut berbagai aspek kehidupan, serta merupakan parameter kemampuan Negara dalam menyelenggarakan pelayanan kesehatan terhadap masyarakat. Kesehatan reproduksi wanita berpe-ngaruh besar dan berperan penting terhadap kelanjutan generasi penerus suatu Negara. ${ }^{1}$

Salah satu masalah kesehatan reproduksi wanita ialah mioma uteri dengan insidensi yang terus meningkat. ${ }^{2}$ Mioma uteri sering ditemukan pada wanita usia reproduksi (20-25\%), tetapi faktor penyebab tidak diketahui secara pasti. Mioma jarang sekali ditemukan sebelum usia pubertas, sangat dipengaruhi oleh hormon reproduksi, dan hanya bermanifestasi selama usia reproduksi. ${ }^{3}$

Penyakit reproduksi yang banyak diderita oleh wanita Indonesia ialah mioma uteri. Jumlah kejadian penyakit ini di Indonesia menempati urutan kedua setelah kanker serviks. ${ }^{4}$ Mioma uteri merupakan suatu pertumbuhan jinak dari sel-sel otot polos uterus. Neoplasma jinak ini berasal dari otot uterus serta jaringan ikat penyerta, sehingga dikenal istilah fibromioma, leiomioma, ataupun fibroid. ${ }^{5}$ Mioma uteri merupakan jenis tumor uterus yang paling sering. Diduga $20 \%$ dari wanita berusia 35 tahun menderita mioma uteri, walaupun tidak disertai dengan gejala-gejala. ${ }^{6}$

Tingginya kejadian mioma uteri pada usia 35-50 tahun menunjukkan adanya hubungan mioma uteri dengan estrogen pada usia reproduksi. Pada usia sebelum menarche kadar estrogen rendah, dan meningkat pada usia reproduksi, serta akan menurun pada usia menopause. ${ }^{7}$ Mioma uteri belum pernah dilaporkan terjadi sebelum menarche; dan pada menopause angka kejadian sekitar 10\%. Di Indonesia angka kejadian mioma uteri ditemukan 2,39-11,87\% dari semua pasien ginekologi yang dirawat. ${ }^{8}$

Mioma uteri memiliki banyak faktor risiko, yang meningkat seiring dengan peningkatan usia. Kasus mioma uteri terbanyak pada kelompok usia 40-49 tahun, dengan usia rata-rata 42,97 tahun sebanyak $51 \%$. Risiko mioma uteri meningkat pada wanita nullipara. Mioma umumnya ditemukan pada wanita usia reproduksi, dan belum pernah dilaporkan terjadi sebelum menarche. Pada masa menopause, mioma akan mengecil seiring dengan penurunan hormon estrogen dalam tubuh. ${ }^{3}$

Penelitian Marino (2004) di Italia melaporkan 73 kasus mioma uteri dari 341 wanita yang terjadi pada usia 30-60 tahun dengan prevalensi 21,4\%. Penelitian Boynton (2005) di Amerika melaporkan 7.466 kasus mioma uteri dari 827.348 wanita berusia 25-42 tahun dengan prevalensi $0,9 \%$. Penelitian Bhat (2006) di India (Departement of Obstetrics and Gynecology, Kasturba Medical College and Hospital) mendapatkan 150 kasus mioma uteri, dan 77 kasus terjadi pada wanita berusia 40-49 tahun dengan prevalensi $51 \%$, dan 45 kasus terjadi pada wanita berusia lebih dari 50 tahun dengan prevalensi $30 \%{ }^{9}$

Menurut Wijaya (2005), di RSUP Prof. Dr. R.D. Kandou Manado terdapat 106 kasus mioma uteri, dan terbanyak pada golongan usia 36-45 tahun yaitu sekitar 55 kasus $(57,3 \%){ }^{10}$

\section{METODE PENELITIAN}

Penelitian ini merupakan jenis penelitian observasi analitik deskriptif retrospektif dengan metode cross sectional. Sumber data yang digunakan ialah data sekunder yang dikumpulkan dari rekam medis dan buku register RSUP Prof. DR. R. D. kandou Manado periode 1 Maret 2012 - 31 Oktober 2012. Subyek penelitian yaitu pasien wanita berusia 18-49 dengan mioma uteri. Variabel bebas ialah usia reproduksi 18-49 tahun sedangkan variabel terikat yaitu kejadian mioma uteri. Analisis bivariat dipakai untuk membuktikan hubungan variabel dengan menggunakan Chi square test. Pada tingkat kepercayaan 95\% $(\alpha \leq 0,05)$, jika $P \leq 0,05$ maka terdapat hubungan antara variabel bebas dan variabel terikat. 


\section{HASIL PENELITIAN}

Berdasarkan hasil penelitian retrospektif, tercatat jumlah semua kasus berusia 1849 tahun yang terdiagnosis menderita penyakit ginekologi di Bagian Obstetri Ginekologi RSUP Prof. Dr. R.D. Kandou Manado periode 1 Maret - 31 Oktober 2012 sebanyak 353 pasien, dan terbanyak pada usia 34-49 tahun $(69,1 \%)$ (Tabel 1).

Tabel 1. Distribusi frekuensi usia reproduksi periode 1 Maret 2012 - 31 Oktober 2012.

\begin{tabular}{ccc}
\hline Usia reproduksi & Frekuensi & \% \\
\hline 18-33 tahun & 109 & $30,9 \%$ \\
34-49 tahun & 244 & $69,1 \%$ \\
Jumlah & 353 & $100 \%$ \\
\hline
\end{tabular}

Dari data rekam medis pasien berusia 18-49 tahun, kasus non-mioma uteri ditemukan sebanyak 245 orang $(69,4 \%)$, sedangkan kasus mioma uteri 108 orang $(30,6 \%)$.

Tabel 2. Distribusi frekuensi angka kejadian penyakit ginekologi di Bagian Obstetri Ginekologi RSUP Prof. Dr. R.D. Kandou Manado periode 1 Maret 2012-31 Oktober 2012.

\begin{tabular}{lcc}
\hline $\begin{array}{l}\text { Kejadian } \\
\text { mioma Uteri }\end{array}$ & Frekuensi & $\mathbf{\%}$ \\
\hline $\begin{array}{l}\text { Non-mioma } \\
\text { uteri }\end{array}$ & 245 & $69.4 \%$ \\
Mioma uteri & 108 & $30.6 \%$ \\
Jumlah & 353 & $100 \%$ \\
\hline
\end{tabular}

Hasil penelitian menunjukkan bahwa pada kelompok usia 18-33 tahun kasus non-mioma uteri $(41,6 \%)$ lebih banyak dibandingkan kasus mioma (6,5\%). Berbeda halnya dengan kelompok usia 34-39 tahun, kasus non-mioma uteri sebesar 58,4\% sedangkan kasus mioma uteri 93,5\%.

\section{BAHASAN}

Distribusi frekuensi berdasarkan usia reproduksi memperlihatkan bahwa pasien rawat inap di Bagian Obstetri-Ginekologi RSUP Prof. Dr. R.D. Kandou Manado periode 1 Maret - 31 Oktober 2012, terbanyak berusia 34-49 tahun $(69,1 \%)$ dibandingkan usia 18-33 tahun (Tabel 1). Manuaba (2009) mengemukakan bahwa seiring dengan dimulainya usia reproduksi, maka mulai terjadi berbagai masalah yang berhubungan dengan kesehatan reproduksi atau alat reproduksi. ${ }^{1}$

Pada penelitian ini, distribusi angka kejadian penyakit ginekologi di Bagian Obstetri Ginekologi RSUP Prof. Dr. R.D. Kandou Manado pasien rawat inap terbanyak terdapat pada kelompok nonmioma uteri yang berusia 18-49 tahun, yaitu sebanyak 245 kasus $(69,4 \%)$, sedangkan yang menderita mioma uteri yaitu sebanyak 108 kasus $(30,6 \%)$ pada usia antara 18-49 tahun (Tabel 2).

Berdasarkan hasil penelitian, Bagian Obstetri-Ginekologi mioma uteri menempati urutan pertama dari semua penyakit ginekologi. Hal ini sesuai dengan Norwitz (2007) yang menyatakan hampir sepertiga kasus ginekologi merupakan mioma uteri, dengan angka estimasi mioma uteri $25-30 \%$

Tabel 3. Hubugan usia reproduksi dengan kejadian mioma uteri periode 1 Maret - 31 Oktober 2012.

\begin{tabular}{|c|c|c|c|c|c|c|c|}
\hline \multirow{3}{*}{$\begin{array}{c}\text { Usia } \\
\text { reproduksi } \\
\text { (tahun) }\end{array}$} & \multicolumn{4}{|c|}{ Kejadian penyakit ginekologi } & \multirow{2}{*}{\multicolumn{2}{|c|}{ Total }} & \multirow[t]{3}{*}{$P=0,000$} \\
\hline & \multicolumn{2}{|c|}{ Non-mioma } & \multicolumn{2}{|c|}{ Mioma } & & & \\
\hline & $\mathbf{N}$ & $\%$ & $\mathbf{N}$ & $\%$ & $\mathbf{N}$ & $\%$ & \\
\hline $18-33$ & 102 & 41,6 & 7 & 6,5 & 109 & 30,9 & \\
\hline $34-49$ & 143 & 58,4 & 101 & 93,5 & 244 & 69,1 & \\
\hline Jumlah & 245 & 100 & 108 & 100 & 353 & 100 & \\
\hline
\end{tabular}


pada usia reproduksi. Klatsky et al (2008) ${ }^{11}$ dan Wiknjosastro (1999) ${ }^{4}$ menyatakan bahwa estrogen sangat berperan dalam terjadinya mioma uteri dimana kadar estrogen tinggi pada masa usia reproduktif. Pada usia menopause terjadi regresi mioma uteri karena kedua ovarium sudah tidak menghasilkan estrogen lagi. Pada usia sebelum menarche kadar estrogen rendah., ${ }^{4,11}$

Pada Tabel 3 yaitu identifikasi hubungan usia reproduksi dengan kejadian mioma uteri, dapat dilihat bahwa yang tidak menderita mioma uteri pada usia 1833 tahun sebanyak $41,6 \%$, sedangkan pada usia 34-49 tahun 58,4\%. Pada pasien mioma uteri, usia 18-49 tahun terdapat 108 kasus, dimana usia 34-49 tahun merupakan kasus terbanyak dengan mioma uteri (101 kasus, 93,5\%), dan yang berusia 18-33 tahun hanya sedikit (tujuh kasus, 6,5\%). Hal ini sesuai dengan penelitian Flynn yang menunjukkan bahwa mioma uteri biasanya terjadi selama masa reproduksi, tersering pada usia 35-49 tahun. ${ }^{12}$ Frekuensi kejadian mioma uteri tertinggi pada usia 35-50 tahun yaitu mendekati angka $40 \%$, sangat jarang ditemukan pada usia di bawah 20 tahun, sedangkan pada usia menopause hampir tidak pernah ditemukan. ${ }^{4}$

Hasil penelitian hubungan usia reproduksi dengan kejadian mioma uteri di RSUP Prof. Dr. R. D. Kandou Manado menunjukkan hasil yang sangat bermakna $(P=0,000)$. Dalam uji Pearson Chi-Square diperoleh nilai 43,394 dengan $P=0,000$. Hasil ini menunjukkan terdapatnya hubungan yang sangat bermakna antara usia reproduksi dengan kejadian mioma uteri $(P$ $=0,000, \alpha=0,01)$. Hal ini sesuai dengan penelitian Pojianto dan Mewengkang yang menyatakan bahwa, tingginya kejadian mioma uteri pada usia 35-50 tahun menunjukkan adanya hubungan mioma uteri dengan estrogen usia reproduksi. ${ }^{8}$ Mioma jarang sekali ditemukan sebelum usia pubertas, sangat dipengaruhi oleh hormon reproduksi, dan hanya bermanifestasi selama usia reproduksi. ${ }^{3}$ Pada penelitian sebelumnya oleh Lihawa Muis di RSUP Prof. Dr. R.D. Kandou Manado 2005 dilaporkan bahwa 57,3\% kasus terjadi pada golongan umur 36-49 tahun. ${ }^{10}$

\section{SIMPULAN}

Dari hasil penelitian di Bagian Obstetri-Ginekologi RSUP Prof. Dr. R.D. Kandou Manado periode 1 Maret - 31 Oktober 2012 dapat disimpulkan bahwa pada pasien yang berusia 18-49 tahun ditemukan kasus ginekologi terbanyak ialah mioma uteri dengan usia tersering 3449 tahun.

\section{UCAPAN TERIMA KASIH}

Ucapan terima kasih ditujukan pada para dosen penguji yang telah meluangkan waktu, memberikan masukan, saran, dan kritik, serta semua pihak baik secara langsung maupun tidak langsung telah menumbuhkan ide sehingga penulis dapat menyelesaikan penulisan artikel ini.

\section{DAFTAR PUSTAKA}

1. Manuaba IBG, Manuaba IAC. Memahami Kesehatan Reroduksi Wanita (Edisi Kedua). Jakarta: EGC, 2009.

2. Schwartz SI. Intisari Prinsip-Prinsip Ilmu Bedah (Edisi Keenam). Jakarta: Penerbit EGC, 2000.

3. Prawirohardjo S, Wiknjosastro $H$, Sumapraja S. Ilmu Kandungan (Edisi Ketiga). Jakarta: Yayasan Bina Pustaka Sarwono, 2011; hal.12, 274-278.

4. Wiknjosastro H. Ilmu Kandungan. Jakarta: Yayasan Bina Pustaka Sarwono Prawirohardjo, 1999.

5. Rayburn FW, Carey CJ. Obstetri dan Ginekologi. Jakarta: Widya Medika, 2001; hal. 268-70.

6. Sastrawinata SR. Ginekologi. Bagian Obstetri \& Ginekologi (Edisi Kedua). Bandung: FK-UNPAD, 2010; hal. 154-9.

7. Ganong, William F. Buku Ajar Fisiologi Kedokteran (Edisi Kedua). Jakarta: EGC, 2008.

8. Pojianto, Mewengkang RAA. Penggunaan GnRH agonis pada mioma uteri [serial online]. 2012 [cited 2012 Oct 28];(38)5. Available from http://www.Jurnal medika.com. 
30 Jurnal e-CliniC (eCl), Volume 1, Nomor 1, Maret 2013, hlm. 26-30

9. Lilyani DI, Sudiat M, Basuki R. Hubungan faktor risiko dengan kejadian mioma uteri di RSUD Tugurejo Semarang [KTIS]. Semarang: FKU-UM; 2011.

10. Wijaya NAK. Karakteristik penyakit mioma uteri di BLU RSUP Prof. Dr. R.D. Kandou Manado Periode 1 Januari 2009-31 Desember 2010 [Skripsi]. Manado: FKU-Unsrat; 2011.

11. Klatsky PC, Tran ND, Caughey AB, Fujimoto VY. Fibroids and reproductive outcomes: a systematic literature review from conception to delivery. American Journal of Obstetrics and Gynecology. 2008:357-8.

12. Flynn M. Health care resource use for uterine fibroid tumors in the United States. American Journal of Obstetrics and Gynecology [homepage on the Internet]. 2006 [cited 2012 Oct 23] Available from: 